\title{
Completion of the Amino Acid Sequence of Papain
}

\author{
By S. S. HUSAIN AND G. LOWE \\ The Dyson Perrins Laboratory, University of Oxford
}

(Received 8 April 1969)

\begin{abstract}
Papain was inhibited with bromo[2-14C]acetic acid, the tertiary structure of the inhibited enzyme was unfolded and the disulphide bridges were reduced with mercaptoethanol and aminoethylated. Digestion with trypsin gave a radioactive peptide consisting of residues 18-58 inclusive and containing therefore the sequence of the thirteen unknown residues 29-41 in the primary sequence of papain. This peptide was digested with pepsin to give a radioactive peptide consisting of residues 18-47, which after digestion with $0.4 \mathrm{M}$-hydrochloric acid gave a radioactive peptide consisting of residues 24-43 inclusive. Further digestion with $6 \mathrm{M}$-hydrochloric acid gave peptides that were used to determine the sequence:
\end{abstract}

\section{Ser-Ala-Val-Val-Thr-Ile-Glx-Gly-Ile-Ile-Lys-Ile-Arg}

for the residues 29-41, so completing the amino acid sequence of papain.

The X-ray crystal-structure analysis of papain, the cysteine proteinase from papaya latex (Drenth, Jansonius, Koekoek, Swen \& Wolthers, 1968), in addition to elucidating the tertiary structure of the enzyme, showed that the tentative amino acid sequence (Light, Frater, Kimmel \& Smith, 1964) required considerable revision. It also indicated that the amino acids from residue 29 to residue 41 (with the exception of the dipeptide isoleucylisoleucine) had not been isolated during the degradative studies. It seemed significant that the sequence from residue 26 to residue 41 formed an extensive piece of $\alpha$-helix running from the surface of the molecule right into the core of the tertiary structure, and probably consisted mainly therefore of hydrophobic residues.

The active-site cysteine residue of papain has been identified as residue 25 (Light et al. 1964; Husain \& Lowe, 1965) and is therefore conveniently placed for specifically labelling the molecule close to the sequence of the thirteen unknown residues. By taking advantage of this fact, a radioactive peptide containing the sequence of thirteen unknown residues was readily obtained. The sequence of these residues has now been determined, so completing the amino acid sequence of papain.

\section{EXPERIMENTAL}

Detection of peptides. All radioactivity measurements were made in solution in a Beckman DPM-100 liquidscintillation counter.

Non-radioactive peptides were detected either by measuring the extinction at $280 \mathrm{~nm}$. or by measuring the extinction at $570 \mathrm{~nm}$. after reaction of the alkaline hydrolysate with ninhydrin (see Hirs, Moore \& Stein, 1956).

Paper chromatography. All paper chromatograms were run on Whatman 3MM paper with butan-1-ol-acetic acidwater $(40: 6: 15$, by vol.) as solvent.

Amino acid analyses. Peptides (approx. $9 \cdot 1 \mu$ mole) were hydrolysed with $6 \mathrm{M}-\mathrm{HCl}\left(2 \mathrm{ml}\right.$.) at $110^{\circ}$ in a sealed evacuated tube for 18-96 hr. as indicated. The hydrolysate was evaporated to dryness under reduced pressure and the residue taken up in $0.1 \mathrm{M}-\mathrm{HCl}$. The amino acid analyses were performed on a Technicon AutoAnalyzer with the buffer system of Thomson \& Miles (1964). The analyses are not corrected for decomposition during hydrolysis.

Edman degradations. These were performed as described by Gray (1967).

Papain. Twice-crystallized papain was prepared from granular papaya latex (we are grateful to the Wallerstein Co., New York, N.Y., U.S.A., for a generous gift of this material) by the method of Kimmel \& Smith (1954). Enzyme concentrations were determined from the extinction at $278 \mathrm{~nm}$. (Glazer \& Smith, 1961). Enzyme activity was assayed by the rate of hydrolysis of methyl hippurate on a Radiometer pH-stat (Lowe \& Williams, 1965).

Inhibition of papain with bromo[2-14C]acetic acid. Papain $(0.81 \mathrm{~g}$.) in $0.025 \mathrm{M}$-sodium citrate buffer, $\mathrm{pH} 5.5(150 \mathrm{ml}$.), was activated with cysteine hydrochloride $(0 \cdot 12 \mathrm{~g}$.$) and$ EDTA $(0.06 \mathrm{~g}$.$) , and then completely and irreversibly$ inhibited with bromo[2-14 C]acetic acid $(0.1 \mathrm{mc} ; 18.5 \mathrm{mg}$.). The excess of reagents was removed by gel filtration on a column (45 cm. $\times 4 \mathrm{~cm}$.) of Sephadex G-25 (fine grade).

Reduction and aminothylation of the inhibited papain. The solution of the inhibited enzyme was evaporated to dryness in a rotary evaporator and the residue dissolved in $6 \mathrm{M}$-guanidinium chloride $(75 \mathrm{ml}$.) in $1.0 \mathrm{M}$-tris- $\mathrm{HCl}$ buffer, pH 8.6. Mercaptoethanol $(0 \cdot 8 \mathrm{ml}$.) was added and the solution kept under $\mathrm{N}_{2}$ at $25^{\circ}$ for $4 \mathrm{hr}$. Ethyleneimine $(3 \mathrm{ml}$.) was added in three $1 \mathrm{ml}$. portions at $10 \mathrm{~min}$. intervals 
(see Raftery \& Cole, 1966). After $30 \mathrm{~min}$. the solution was concentrated to $60 \mathrm{ml}$. in a rotary evaporator and the protein separated from reagents on a column of Sephadex G-25 with aq. $50 \%$ (v/v) acetic acid.

Digestion with trypsin. Most of the acetic acid was removed from the protein solution in a rotary evaporator by concentrating, adding water and again concentrating several times. The solution was made up to $50 \mathrm{ml}$. with $0 \cdot 1 \mathrm{M}-\mathrm{KCl}$. The solution was brought to $\mathrm{pH9} 4$ with $2 \mathrm{M}$ $\mathrm{NaOH}$ solution, $0.5 \mathrm{M}$-calcium acetate (1 ml.) was added and the papain was digested with trypsin that had been treated with diphenylcarbamoyl chloride (20 mg.; Seravac Laboratories Ltd., Maidenhead, Berks.). The pH was maintained by adding $0.5 \mathrm{M}-\mathrm{NaOH}$ in a pH-stat. After $2 \mathrm{hr}$., more trypsin $(4.5 \mathrm{mg}$.) was added and the digestion continued for a further $1 \mathrm{hr}$. The digestion was stopped by adjusting the $\mathrm{pH}$ to 3.8 with acetic acid. The digest was concentrated in a rotary evaporator to approx. $3 \mathrm{ml}$., and taken up in aq. $50 \%(\mathrm{v} / \mathrm{v})$ acetic acid $(20 \mathrm{ml}$.$) .$

Gel filtration of the tryptic digest. The digest was passed through a column $(45 \mathrm{~cm} . \times 3.5 \mathrm{~cm}$.) of Sephadex G-25 (fine grade) with aq. $50 \%(\mathrm{v} / \mathrm{v})$ acetic acid containing $0.2 \%$ of thiodiglycol. All the radioactivity emerged immediately after the void volume of the column. The radioactive fractions were combined, concentrated to $5 \mathrm{ml}$. in a rotary evaporator, and passed through a column $(150 \mathrm{~cm} . \times 1 \mathrm{~cm}$. of Sephadex G-50 (fine grade) with aq. $50 \%(\mathrm{v} / \mathrm{v})$ acetic acid containing $0.2 \%$ of thiodiglycol. The chromatogram is shown in Fig. 1.

Fractions 49-61 were combined and a sample, run on paper chromatography, gave a single spot at the origin. The amino acid analysis is shown in Table 1. Fractions 76-86 were combined and the radioactive peptide separated

\section{Table 1. Amino acid analyses of the acid hydrolysates of the radioactive peptide (I)}

Both combined fractions gave a positive reaction with Ehrlich reagent. The period of digestion is given above each analysis. Abbreviations: CMCys, S-carboxymethylcysteine; AECys, $S$-aminoethylcysteine.

\begin{tabular}{|c|c|c|c|c|}
\hline \multirow[b]{2}{*}{ Amino acid } & \multicolumn{2}{|c|}{$\begin{array}{c}\text { Fractions 49-61 } \\
\text { (Fig. 1) }\end{array}$} & \multicolumn{2}{|c|}{$\begin{array}{c}\text { Fractions 46-52 } \\
\text { (Fig. 2) }\end{array}$} \\
\hline & $18 \mathrm{hr}$. & $90 \mathrm{hr}$. & $24 \mathrm{hr}$. & $90 \mathrm{hr}$. \\
\hline CMCys & 0.7 & 0.7 & 0.8 & 0.7 \\
\hline Asp & $4 \cdot 7$ & $4 \cdot 5$ & $5 \cdot 0$ & $4 \cdot 7$ \\
\hline Thr & $2 \cdot 0$ & 1.9 & $1 \cdot 7$ & 1.9 \\
\hline Ser & $4 \cdot 0$ & $3 \cdot 3$ & $3 \cdot 4$ & $2 \cdot 6$ \\
\hline Glu & $6 \cdot 0$ & $6 \cdot 1$ & $6 \cdot 2$ & 6.0 \\
\hline Pro & $\sim 0.1$ & $\sim 0.1$ & 0 & 0 \\
\hline Gly & $\mathbf{3 \cdot 9}$ & $4 \cdot 0$ & $4 \cdot 1$ & $4 \cdot 2$ \\
\hline Ala & $2 \cdot 3$ & $2 \cdot 3$ & $2 \cdot 0$ & $2 \cdot 3$ \\
\hline Val & $1 \cdot 7$ & $2 \cdot 3$ & 1.0 & $2 \cdot 1$ \\
\hline Ile & $2 \cdot 7$ & $4 \cdot 2$ & $2 \cdot 0$ & $3 \cdot 9$ \\
\hline Leu & $3 \cdot 1$ & $3 \cdot 1$ & $2 \cdot 9$ & $2 \cdot 8$ \\
\hline Tyr & $1 \cdot 2$ & $1 \cdot 2$ & 1.0 & 0.9 \\
\hline Phe & $1 \cdot 2$ & $1 \cdot 2$ & 1.0 & $1 \cdot 0$ \\
\hline AECys & $1 \cdot 3$ & $1 \cdot 6$ & $1 \cdot 6$ & $1 \cdot 6$ \\
\hline Lys & $1 \cdot 3$ & $1 \cdot 3$ & 0.9 & $1 \cdot 1$ \\
\hline Arg & $1 \cdot 7$ & 1.8 & $1 \cdot 6$ & 1.8 \\
\hline
\end{tabular}

from several non-radioactive peptides by paper chromatography. The radioactive material was eluted from the paper with aq. $75 \%(v / v)$ formic acid. The eluate was concentrated to $1 \mathrm{ml}$. and passed through a column $(150 \mathrm{~cm} . \times$ $1 \mathrm{~cm}$.$) of Sephadex G-50 with aq. 50\% (v/v) acetic acid$ containing $0.2 \%$ of thiodiglycol. The radiochromatogram is shown in Fig. 2. The amino acid analysis of the combined fractions 46-52 is shown in Table 1.

Treatment of the radioactive peptide $(0.1 \mu$ mole) with carboxypeptidase $A$ at $\mathrm{pH} 7.8$ and $25^{\circ}$ for $24 \mathrm{hr}$. did not release any amino acids, but with carboxypeptidase $B$ under the same conditions 1 residue of arginine/mol. was released.

Digestion of the radioactive peptide (I) (fractions 49-61, Fig. 1) with pepsin. The radioactive peptide (6 $\mu$ moles) in $0 \cdot 1 \mathrm{M}-\mathrm{HCl}(10 \mathrm{ml}$.) was digested with pepsin (1 mg., thricecrystallized; Seravac Laboratories Ltd.) for $24 \mathrm{hr}$. at $30^{\circ}$. The digestion was stopped by immersing the solution in boiling water for $2 \mathrm{~min}$. The solution was concentrated to $4 \mathrm{ml}$. and passed through a column $(160 \mathrm{~cm} . \times 2 \mathrm{~cm}$.) of Sephadex G-25 (fine grade) with aq. $50 \%$ (v/v) acetic acid containing $0.2 \%$ of thiodiglycol. The chromatogram is shown in Fig. 3. The following fractions were combined: 40-44, 59-64 and 68-72. The amino acid analyses for their hydrolysates are shown in Table 2.

Digestion of the radioactive peptides (II) (fractions 40-44, Fig. 3) with 0.4 m-hydrochloric acid. Fractions 40-44 (Fig. 3) were evaporated to dryness in a rotary evaporator and the residue was taken up in $0.4 \mathrm{M}-\mathrm{HCl}(5 \mathrm{ml}$.). The solution was kept at $110^{\circ}$ for $5 \mathrm{hr}$. in a sealed evacuated tube. The solution was evaporated to dryness in a rotary evaporator, and the residue dissolved in aq. $50 \%(\mathrm{v} / \mathrm{v})$ acetic acid $(1 \mathrm{ml}$. and passed through a column $(140 \mathrm{~cm}, \times 1 \mathrm{~cm}$.) of Sephadex G-25 (fine grade) with aq. $50 \%(v / v)$ acetic acid containing $0 \cdot 2 \%$ of thiodiglycol. The chromatogram is shown in Fig. 4 . The following fractions were combined: 42-48, 82-88, 103-107 and 114-120. The combined fractions 82-88 and 103-107 were purified by paper chromatography before hydrolysis and amino acid analyses. Fractions 114-120 contained mainly aspartic acid with some serine and glycine. The amino acid analyses are shown in Table 3.

Digestion of the radioactive peptide (III) (fractions 42-48, Fig. 4) with 6м-hydrochloric acid. Fractions 42-48 (Fig. 4) were combined and evaporated to dryness in a rotary evaporator. The residue in $6 \mathrm{M}-\mathrm{HCl}(2 \mathrm{ml}$.) was kept at $110^{\circ}$ for $2 \mathrm{hr}$. in a sealed and evacuated tube. The solution was evaporated to dryness and the residue in aq. $50 \%(\mathrm{v} / \mathrm{v})$ acetic acid $(1 \mathrm{ml}$.) passed through a column $(140 \mathrm{~cm} . \times 1 \mathrm{~cm}$.) of Sephadex G-25 with aq. 50\% (v/v) acetic acid. The chromatogram is shown in Fig. 5.

(a) Fractions 40-46 (Fig. 5). This material showed on paper chromatography a single spot at the origin. The amino acid analysis of the hydrolysate is shown in Table 4. Treatment with carboxypeptidase $A$ or $B$ did not release any amino acid residues. However, if the peptide $(0 \cdot 2 \mu$ mole) was kept at $95^{\circ}$ in $0.1 \mathrm{M}$-sodium phosphate buffer,

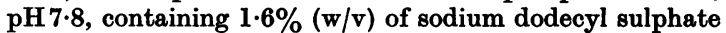
for $24 \mathrm{hr}$., then cooled rapidly to $25^{\circ}$ and treated with carboxypeptidase $B$ that had been freshly purified, arginine $(0.2 \mathrm{residue} / \mathrm{mol}$.) and a smaller proportion of isoleucine were released.

(b) Fractions 52-56 (Fig. 5). The peptide after acid hydrolysis for $48 \mathrm{hr}$. gave the following amino acid analysis (residues/mol.): Gly (0.6), Ile $(2.5 ; 3.0$ after $96 \mathrm{hr}$.), Lys 


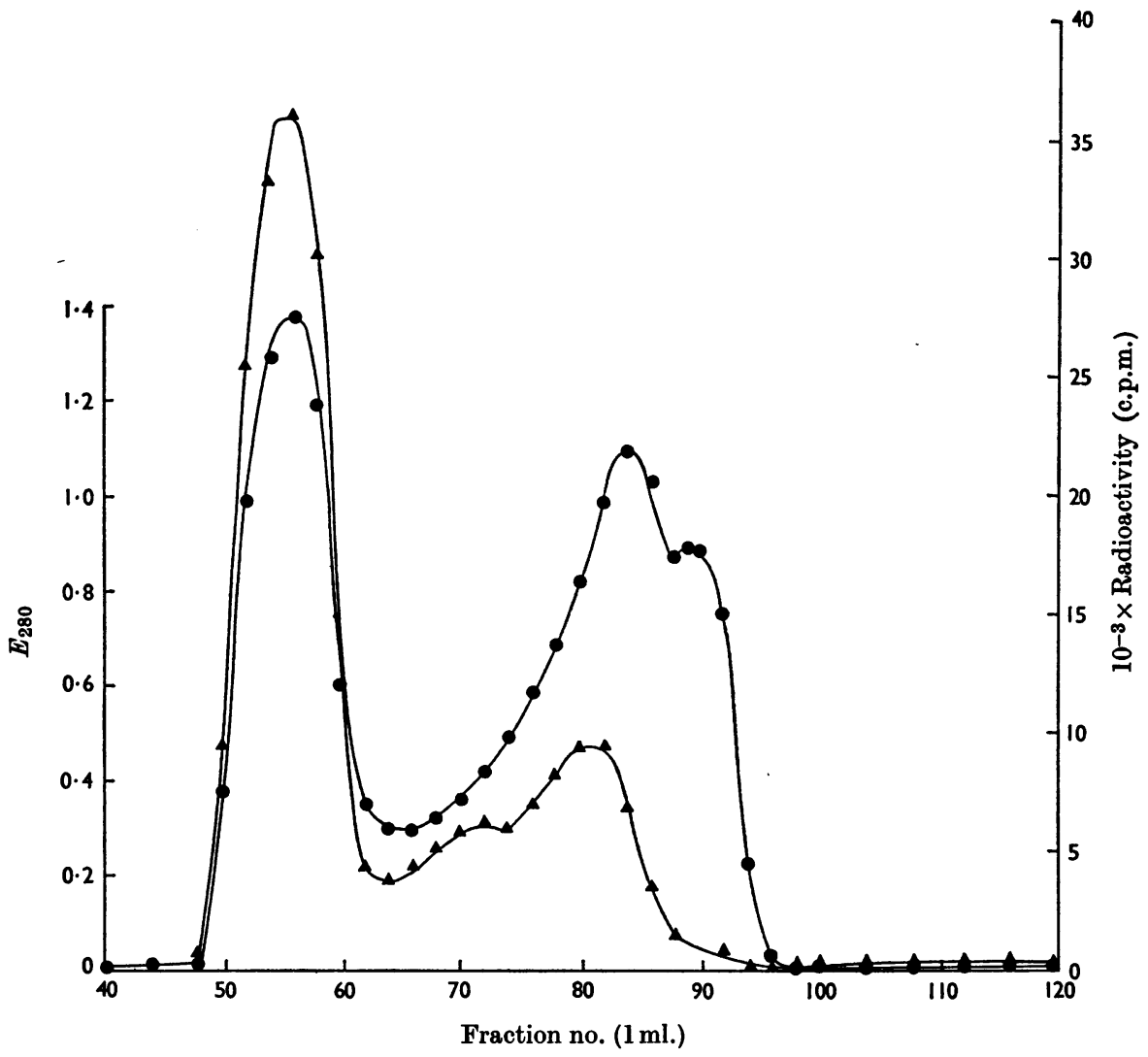

Fig. 1. Gel filtration in aq. $50 \%(v / v)$ acetic acid on Sephadex G-50 of the tryptic digest of bromo[2-14C]acetic acid-inhibited and aminoethylated papain, showing radioactivity $(\Delta)$ and $E_{280}(\bullet)$.

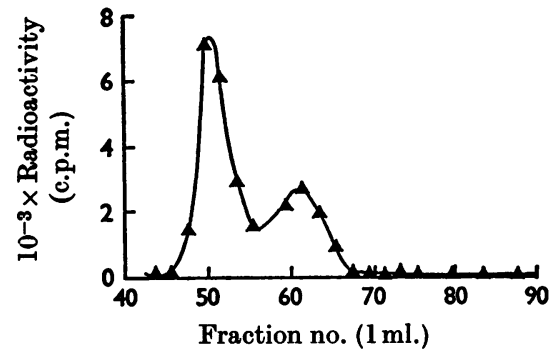

Fig. 2. Gel filtration in aq. $50 \%(v / v)$ acetic acid on Sephar dex G-50 of the radioactive material after paper chromatography of fractions 76-86 (Fig. 1).

(1.0), Arg (0.9). Digestion with carboxypeptidase $B$ in $0 \cdot 1 \mathrm{M}$-sodium phosphate buffer, $\mathrm{pH} \mathrm{7.8}$, at $25^{\circ}$ for $24 \mathrm{hr}$. released 1 residue of arginine $/ \mathrm{mol}$. After one cycle of Edman degradation the residual peptide gave the following amino acid analysis after acid hydrolysis for $96 \mathrm{hr}$. (residues) mol.): Ile (2.5), Lys (1.0), Arg (1.0). The peptide can be assigned therefore the partial sequence:

$$
\text { Gly(Iles,Lys)Arg }
$$

(c) Fractions 60-68 (Fig. 5). These fractions contained two major peptides, which were purified by paper chromatography. The amino acid analysis of one peptide $(22 \mathrm{~cm}$. from the origin) after acid hydrolysis for $48 \mathrm{hr}$. was (residues/ mol.): Ile (1.6; $2 \cdot 1$ after $96 \mathrm{hr}$. digestion), Lys (1.0). After one cycle of Edman degradation the residual peptide after acid hydrolysis for $96 \mathrm{hr}$. gave the following amino acid analysis (residues/mol.): Ile (1·45), Lys (1·0). Digestion of the peptide with carboxypeptidase $B$ for $4 \mathrm{hr}$. released 1 residue of lysine/mol. The peptide must therefore have the sequence:

$$
\text { Ile-Ile-Lys }
$$

The amino acid analysis of the other peptide $(30 \mathrm{~cm}$. from the origin) after acid hydrolysis for $48 \mathrm{hr}$. was (residues/mol.): Thr (0.6), Glu (1·0), Val (1·7), Ile (0.9). Carboxypeptidase A did not effect any digestion. After one cycle of Edman degradation the amino acid analysis of the residual peptide after acid hydrolysis for $48 \mathrm{hr}$. was 


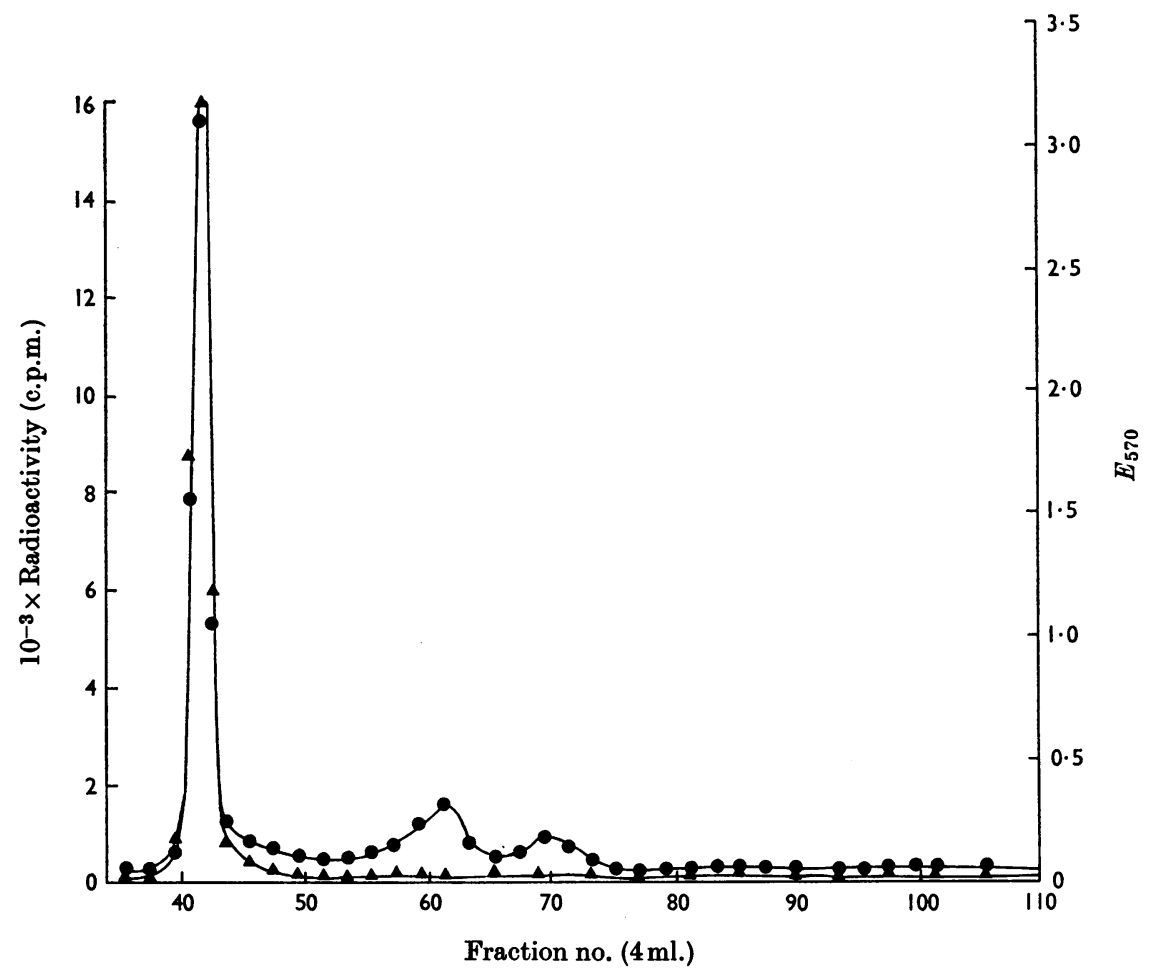

Fig. 3. Gel filtration in aq. 50\% (v/v) acetic acid on Sephadex G-25 of the peptic digest of fractions 49-61 (Fig. 1), showing radioactivity $(\Delta)$ and $E_{570}(\bullet)$ after alkaline hydrolysis and reaction with ninhydrin.

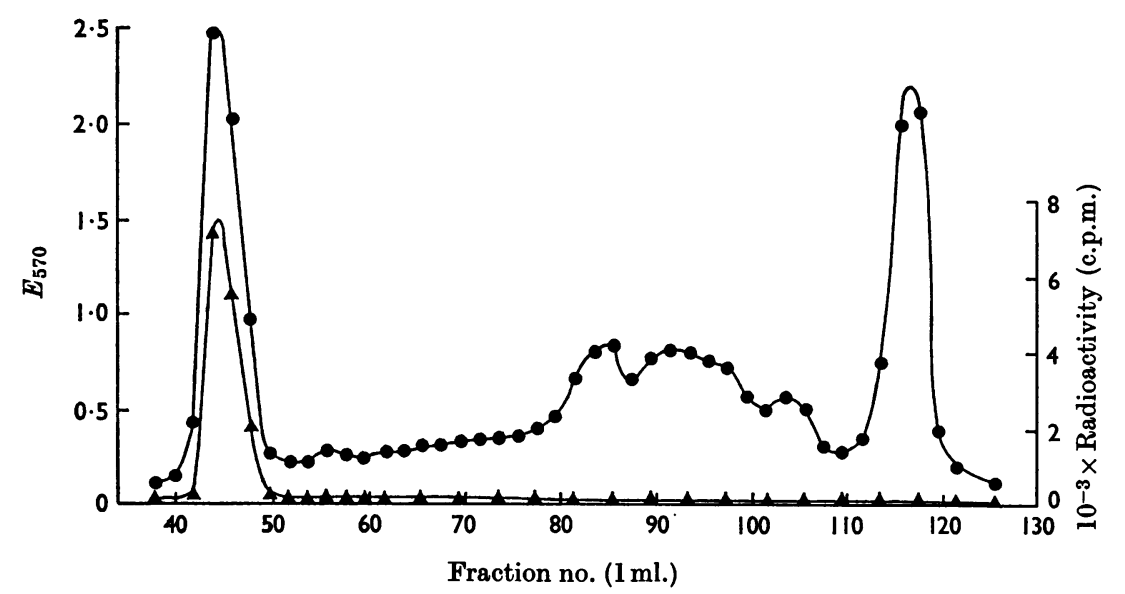

Fig. 4. Gel filtration in aq. $50 \%$ (v/v) acetic acid on Sephadex G-25 of the $0 \cdot 4 \mathrm{M}-\mathrm{HCl}$ digest of fractions $40-44$ (Fig. 3), showing radioactivity $(\Delta)$ and $E_{570}(\bullet)$ after alkaline hydrolysis and reaction with ninhydrin.

(residues/mol.): Thr (0.6), Glu (1.0), Val (1.0), Ile (0.8). The partial sequence must therefore be:

$$
\text { Val(Val,Thr,Ile,Glx) }
$$

(d) Fractions 70-74 (Fig. 5). The amino acid analysis of this peptide after acid hydrolysis for $48 \mathrm{hr}$. and $96 \mathrm{hr}$. was (residues/mol.): Ile (1·2), Arg (1·0). One cycle of Edman degradation released free arginine. The sequence of this peptide must therefore be:

\section{Ile-Arg}


Table 2. Amino acid analyses of the acid hydrolysates of the three peptides obtained by digestion of the radioactive peptide (I) with pepsin

The period of digestion is given above each analysis. Peptide (II) gave a positive reaction with Ehrlich reagent. Abbreviations: CMCys, $S$-carboxymethylcysteine; AECys, $S$-aminoethylcysteine.

\begin{tabular}{|c|c|c|c|c|c|}
\hline Amino acid & $\begin{array}{c}\text { Fractions 40-44 } \\
\text { (Fig. 3) } \\
\text { Peptide (II) } \\
\text { 48hr. }\end{array}$ & Amino acid & $\begin{array}{c}\text { Fractions 59-64 } \\
\text { (Fig. 3) } \\
24 \mathrm{hr} .\end{array}$ & Amino acid & $\begin{array}{l}\text { Fractions 68-72 } \\
\text { (Fig. 3) } \\
\text { 24hr. }\end{array}$ \\
\hline CMCys & 0.7 & Asp & $2 \cdot 1$ & Ser & $1 \cdot 0$ \\
\hline Asp & 3.0 & Leu & $1 \cdot 2$ & Glu & $\mathbf{3} \cdot \mathbf{0}$ \\
\hline Thr & $2 \cdot 1$ & AECys & $1 \cdot 0$ & Leu & 0.9 \\
\hline Ser & $2 \cdot 8$ & Arg & 0.9 & Tyr & $1 \cdot 0$ \\
\hline Glu & $\mathbf{3} \cdot \mathbf{1}$ & & & & \\
\hline Gly & $4 \cdot 3$ & & & & \\
\hline Ala & $2 \cdot 1$ & & & & \\
\hline Val & $1 \cdot 7$ & & & & \\
\hline Ile & $2.9(3.9 \mathrm{a}$ & $96 \mathrm{hr})$. & & & \\
\hline Leu & $1 \cdot 1$ & & & & \\
\hline Tyr & 0 & & & & \\
\hline Phe & $1 \cdot 0$ & & & & \\
\hline AECys & 0.8 & & & & \\
\hline Lys & $1 \cdot 1$ & & & & \\
\hline Arg & $0 \cdot 8$ & & & & \\
\hline
\end{tabular}

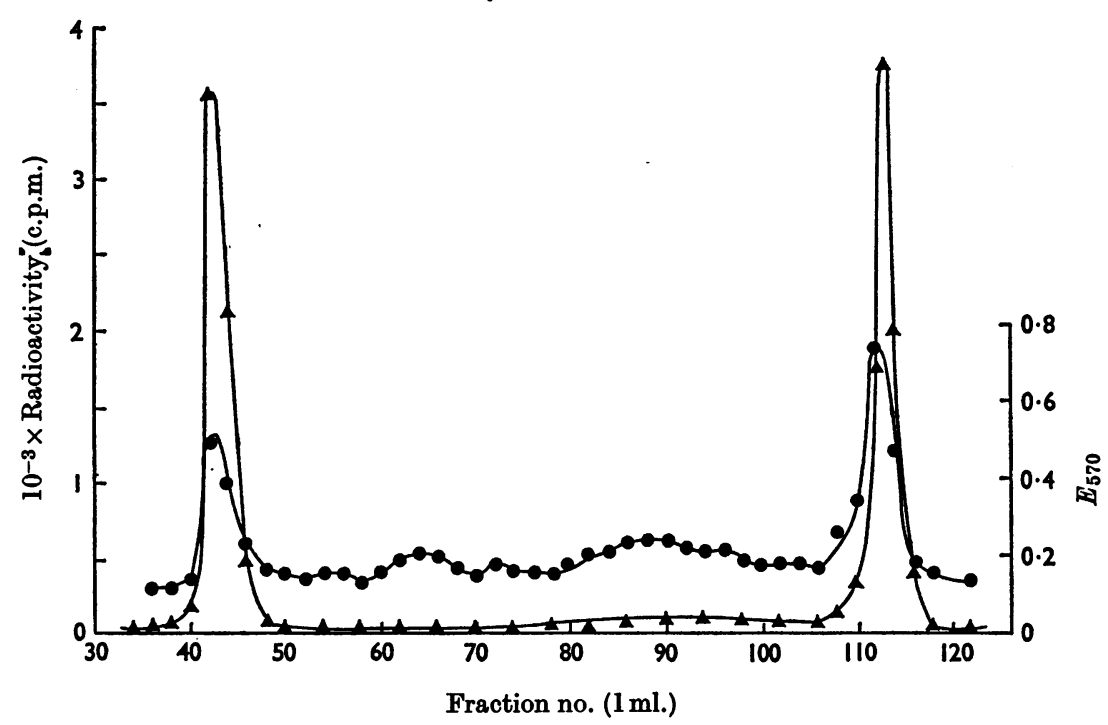

Fig. 5. Gel filtration in aq. $50 \%(\mathrm{v} / \mathrm{v})$ acetic acid on Sephadex G-25 of the $6 \mathrm{M}-\mathrm{HCl}$ digest of fractions $42-48$ (Fig. 4), showing radioactivity $(\Delta)$ and $E_{570}(\bullet)$ after alkaline hydrolysis and reaction with ninhydrin.

(e) Fractions 75-79 (Fig. 5). These fractions were purified by paper chromatography. The amino acid analysis of the major peptide ( $41 \mathrm{~cm}$. from the origin) after acid hydrolysis for $48 \mathrm{hr}$. showed the presence of isoleucine only. Amino acid analysis before hydrolysis showed no isoleucine, and one cycle of Edman degradation released free isoleucine. The peptide must therefore be:

Ile-Ile
The amino acid analysis of the minor peptide $(37 \mathrm{~cm}$. from the origin) after acid hydrolysis for $48 \mathrm{hr}$. was (residues/ mol.): Ala (1.0), Val (1.7). After one cycle of Edman degradation, the amino acid analysis of the resultant peptide after acid hydrolysis for $48 \mathrm{hr}$. showed only valine. The peptide must therefore be:

\section{Ala-Val-Val}

(f) Fractions 80-83 (Fig. 5). These fractions were 
Table 3. Amino acid analyses of the acid hydrolysates of the peptides obtained by digestion of the radioactive peptide (II) with $0.4 \mathrm{M}$-hydrochloric acid

The period of digestion is given above each analysis. Abbreviations: CMCys, $S$-carboxymethylcysteine; AECys, $S$-aminoethylcysteine.

\begin{tabular}{|c|c|c|c|c|c|}
\hline Amino acid & $\begin{array}{c}\text { Fractions 42-48 } \\
\text { (Fig. 4) } \\
\text { Peptide (III) } \\
\text { 48hr. }\end{array}$ & Amino acid & $\begin{array}{c}\text { Fractions 82-88 } \\
\text { (Fig. 4) } \\
\text { 18hr. }\end{array}$ & Amino acid & $\begin{array}{c}\text { Fractions 103-107 } \\
\text { (Fig. 4) } \\
18 \mathrm{hr} .\end{array}$ \\
\hline CMCys & 0.9 & & & & \\
\hline Asp & 0 & Ser & 0.9 & Glu & $1 \cdot 1$ \\
\hline Thr & 1.9 & Gly & 1.0 & Gly & 1.0 \\
\hline Ser & 1.9 & AECys & $1 \cdot 1$ & & \\
\hline Glu & 1.2 & & & & \\
\hline Gly & $2 \cdot 3$ & & & & \\
\hline Ala & $2 \cdot 0$ & & & & \\
\hline Val & $1.5(2.0 \mathrm{af}$ & $96 \mathrm{hr})$. & & & \\
\hline Ile & $3 \cdot 1$ (4. 1 a & $96 \mathrm{hr})$. & & & \\
\hline Leu & 0 & & & & \\
\hline Tyr & 0 & & & & \\
\hline Phe & $1 \cdot 1$ & & & & \\
\hline AECys & 0 & & & & \\
\hline Lys & 1.0 & & & & \\
\hline Arg & $1 \cdot 0$ & & & & \\
\hline
\end{tabular}

Table 4. Amino acid analysis of the acid hydrolysate of peptide (IV)

The peptide was digested with $6 \mathrm{M}-\mathrm{HCl}$ at $110^{\circ}$ for $48 \mathrm{hr}$. Abbreviations: CMCys, S-carboxymethylcysteine; AECys, $S$-aminoethylcysteine.

$\begin{array}{lc} & \begin{array}{c}\text { Fractions 40-46 } \\ \text { (Fig. 5) } \\ \text { Peptide (IV) }\end{array} \\ \text { Amino acid } & 0.7 \\ \text { CMCys } & 0 \\ \text { Asp } & 1.0 \\ \text { Thr } & 1.3 \\ \text { Ser } & 1.0 \\ \text { Glu } & 1.0 \\ \text { Gly } & 2.0 \\ \text { Ala } & 1.6(2.0 \text { after } 96 \mathrm{hr} .) \\ \text { Val } & 3.3(3.9 \text { after } 96 \mathrm{hr} .) \\ \text { Ile } & 0 \\ \text { Leu } & 0 \\ \text { Tyr } & 0.9 \\ \text { Phe } & 0 \\ \text { AECys } & 0.9 \\ \text { Lys } & 1.0 \\ \text { Arg } & \end{array}$

separated into three peptides by paper chromatography. The major peptide $(12 \mathrm{~cm}$. from the origin) gave the following amino acid analysis after acid hydrolysis for $48 \mathrm{hr}$. (residues/mol:): Thr (0.7), Glu (1.0), Ile (1.0, and does not increase after $96 \mathrm{hr}$. hydrolysis). After one cycle of Edman degradation the residual peptide had the following amino acid analysis after acid hydrolysis for $24 \mathrm{hr}$. (residues $/ \mathrm{mol}$.): Thr (0.4), Glu (1.0), Ile (0.9). After a second cycle of Edman degradation free glutamic acid (0.6) was released. The peptide must therefore be:

Thr-Ile-Glu
The second peptide $(25 \mathrm{~cm}$. from the origin) showed only valine on amino acid analysis after acid hydrolysis for $48 \mathrm{hr}$. There was no free valine before acid hydrolysis, and one cycle of Edman degradation released free valine. The peptide must therefore be:

\section{Val-Val}

The third peptide $(35 \mathrm{~cm}$. from the origin) showed only isoleucine on amino acid analysis after acid hydrolysis for $48 \mathrm{hr}$. One cycle of Edman degradation also released free isoleucine. The peptide must therefore be:

\section{Ile-Ile}

(g) Fractions 86-90 (Fig. 5). The fractions were separated by paper chromatography. Free valine, isoleucine and arginine were found together with two peptides. The amino acid analysis of the first peptide after acid hydrolysis for $48 \mathrm{hr}$. was (residues/mol.): Ala (1·1), Phe (1.0). One cycle of Edman degradation released free phenylalanine. The peptide must therefore be:

\section{Ala-Phe}

The amino acid analysis of the second peptide after acid hydrolysis for $24 \mathrm{hr}$. was (residues/mol.): Ser (0.8), Phe (1.0). One cycle of Edman degradation released free serine. The peptide must therefore be:

\section{Phe-Ser}

(h) Fractions 93-97 (Fig. 5). These fractions contained small amounts of peptides, which were inseparable by paper chromatography, but mainly consisted of valine and isoleucine.

(i) Fractions 98-104 (Fig. 5). These fractions contained a mixture of amino acids and dipeptides, which were not separable by paper chromatography.

(l) Fractions 111-116 (Fig. 5). These fractions contained $S$-carboxymethylcysteine, glycine, serine and threonine. 


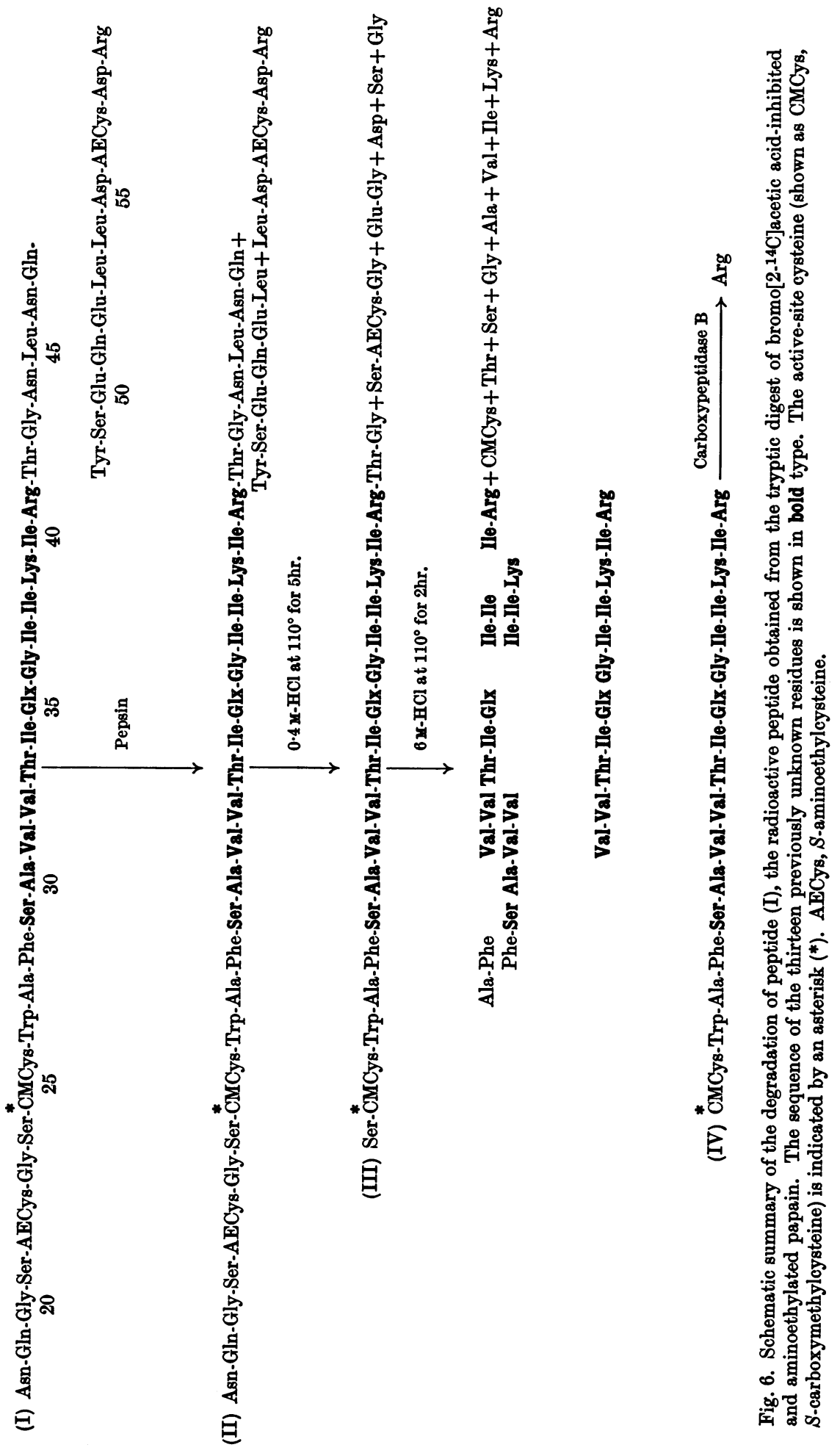




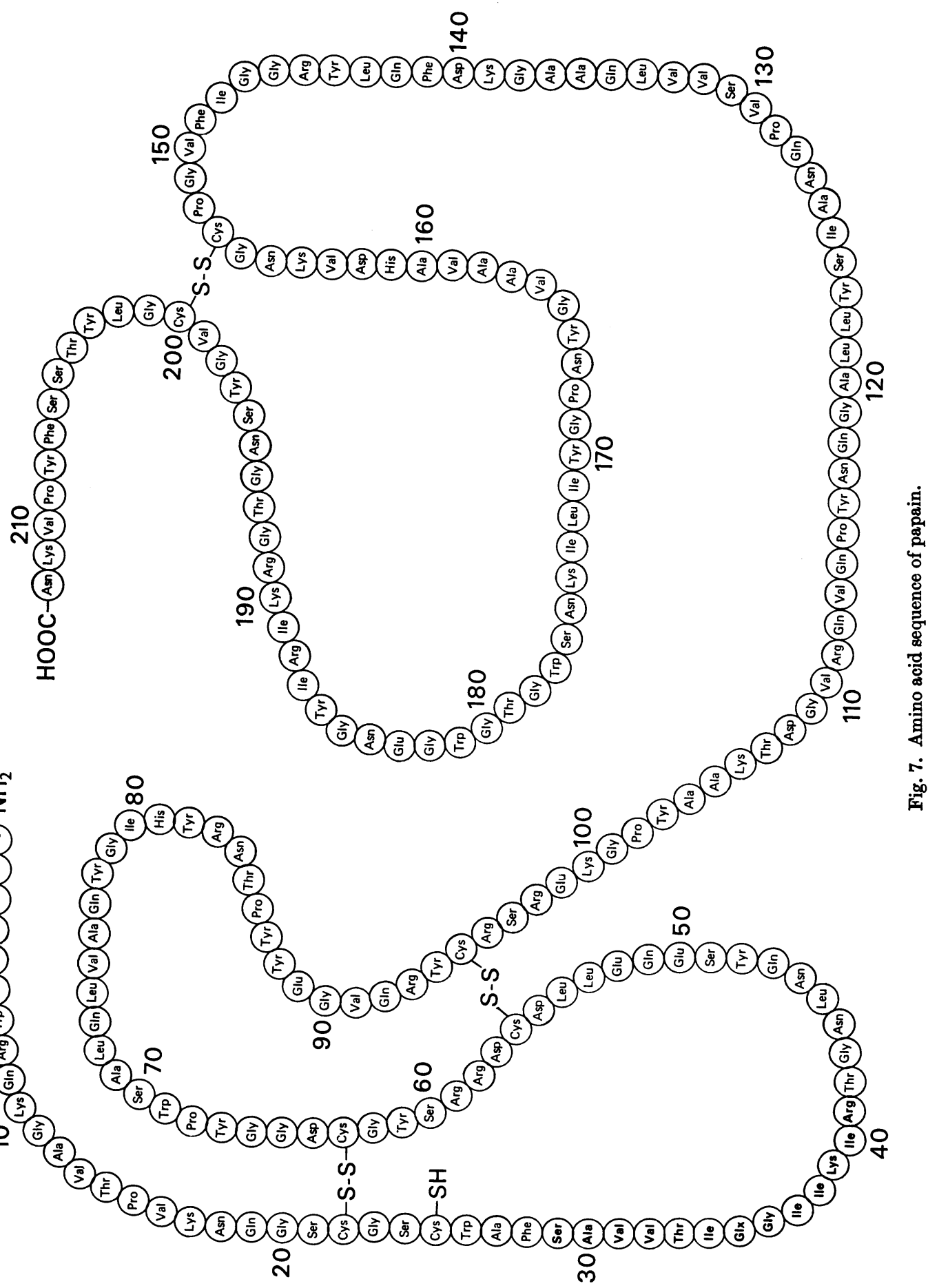




\section{DISCUSSION}

The proximity of the thirteen amino acid residues 29-41 inclusive to the active-site cysteine25 in the primary sequence of papain greatly facilitated the isolation of these unknown residues. The active-site cysteine-25 was labelled by inhibition of papain with radioactive bromoacetic acid. The tertiary structure of the inhibited enzyme was opened, the disulphide bridges were reduced with mercaptoethanol and aminoethylated, and the protein was digested with trypsin. The tryptic digest was taken up in aq. $50 \%(v / v)$ acetic acid (it formed a gel in aqueous solution) and chromatographed on Sephadex G-25. All the radioactivity was eluted at the front (i.e. it emerged immediately after the void volume of the column). When the radioactive material was chromatographed again on Sephadex G-50 (Fig. 1) most of the radioactivity was eluted at the front. The radioactive peptide must therefore have an apparent molecular weight greater than $10^{4}$, and was presumably aggregating. It was not possible, however, to break the aggregate in $6 \mathrm{M}$-guanidinium chloride or $8 \mathrm{M}$-urea solution. Paper chromatography showed no contaminating peptides. The other main radioactive peak (fractions 76-86, Fig. 1) was separated from several non-radioactive peptides on paper and then chromatographed again on Sephadex G-50 (Fig. 2). Elution of radioactive material at the front clearly indicated that further aggregation had occurred. The amino acid analysis of this material was essentially indistinguishable from that of the material eluted at the front from the first Sephadex G-50 column (Fig. 1 and Table 1). It was also completely compatible with the amino acid sequence of papain from residues 18-28 inclusive and 42-58 inclusive, leaving exactly thirteen residues, assuming the presence of only one tryptophan residue. The amino acid composition of the unknown sequence was thus established, and the overlap on the $N$ - and $C$-termini confirmed the revised amino acid sequence proposed by Drenth et al. (1968). The peptide (I) (Fig. 6) was obtained in at least $60 \%$ yield.

To facilitate the determination of the sequence of the thirteen unknown residues, this large peptide (I) (41 residues) was first digested with pepsin, which removed eleven residues from the $C$-terminus. The hexapeptide and pentapeptide removed were isolated (Fig. 3) and their amino acid compositions confirmed (Table 2). The radioactive peptide (II) was eluted at the front from a Sephadex G-25 column (Fig. 3), and its amino acid analysis confirmed the composition of the unknown sequence (Table 2).

Digestion of the radioactive peptide (II) with $0.4 \mathrm{M}$-hydrochloric acid at $110^{\circ}$ for $5 \mathrm{hr}$. removed residues from both the $N$ - and $C$-termini, leaving a radioactive peptide (III) containing only twenty amino acid residues (Table 3, assuming one tryptophan residue). Again it was eluted at the front from a Sephadex G-25 column (Fig. 4). A dipeptide and a tripeptide were also obtained after further purification by paper chromatography (Table 3 and Fig. 6).

The unknown sequence of thirteen residues was now contained in the radioactive peptide (III), but this peptide was so insoluble in aqueous solution that enzymic digestion could not be achieved. Instead the peptide was digested with $6 \mathrm{M}$-hydrochloric acid, in which it was soluble, at $110^{\circ}$ for $2 \mathrm{hr}$. The digest was chromatographed on Sephadex G-25 in aq. 50\% (v/v) acetic acid (Fig. 5). The only radioactive fractions were free $S$-carboxymethylcysteine and the radioactive peptide (IV), now containing only seventeen amino acid residues, including the sequence of thirteen unknown residues. The other peptide-containing fractions were chromatographed on paper, from which ten peptides were isolated (Fig. 6). Determination of the complete sequence of some and the partial sequence of other peptides led to the assignment of serine to residue 29 , but no overlap was obtained between this residue and the $N$-terminus of either of the two hexapeptide sequences, Ala-Val-ValThr-Ile-Glx and Gly-Ile-Ile-Lys-Ile-Arg, or between these hexapeptide sequences. Peptide (IV) was therefore treated with carboxypeptidase $A$ and carboxypeptidase $B$, but no amino acid was released. If, however, peptide (IV) was kept at $95^{\circ}$ for $24 \mathrm{hr}$. in buffer containing sodium dodecyl sulphate and then cooled rapidly to $25^{\circ}$, and carboxypeptidase $B$ was added, arginine and a smaller proportion of isoleucine were released. The sequence of residues 29-41 was therefore established (Fig. 6), so completing the amino acid sequence of papain (Fig. 7). This sequence has an additional residue (Val-130) from the published sequence (Drenth et al. 1968) and arises from a reinterpretation of the refined electron-density map (Drenth, Jansonius, Koekoek, Sluyterman \& Wolthers, 1969); residue 73 is now glutamine rather than glutamic acid (E. L. Smith, unpublished work). The papain molecule therefore has 212 amino acid residues. The active-site cysteine residue remains as residue 25 , but the active-site histidine residue becomes residue 159.

The authors thank the Medical Research Council for a grant to support this work.

\section{REFERENCES}

Drenth, J., Jansonius, J. N., Koekoek, R., Swen, H. M. \& Wolthers, B. G. (1968). Nature, Lond., 218, 929.

Drenth, J., Jansonius, J. N., Koekoek, R., Sluyterman, L. A. E. \& Wolthers, B. G. (1969). Proc. Roy. Soc. B (in the Press). 
Glazer, A. N. \& Smith, E. L. (1961). J. biol. Chem. 236, Kimmel, J. R. \& Smith, E. L. (1954). J. biol. Chem. 207, 2948.

515. Gray, W. R. (1967). In Methods in Enzymology, vol. 11,
p. 469. Ed. by Hirs, C. H. W. New York: Academic Press Inc.

Hirs, C. H. W., Moore, S. \& Stein, W. H. (1956). J. biol. Chem. 219, 623.

Husain, S. S. \& Lowe, G. (1965). Chem. Commun. p. 345.
Light, A., Frater, R., Kimmel, J. R. \& Smith, E. L. (1964). Proc. nat. Acad. Sci., Wash., 52, 1276.

Lowe, G. \& Williams, A. (1965). Biochem. J. 96, 199.

Raftery, M. A. \& Cole, R. D. (1966). J.biol. Chem.241, 3457. Thomson, A. R. \& Miles, B. J. (1964). Nature, Lond., 208, 483. 